ROCZNIKI HUMANISTYCZNE

Tom LXVIII, zeszyt $6-2020$

DOI: http://dx.doi.org/10.18290/rh20686-12

MAŁGORZATA WIDEŁ-IGNASZCZAK

\title{
PERSPEKTYWY BADAŃ SOCJOLINGWISTYCZNYCH \\ W NURCIE TEOLINGWISTYKI SŁOWIAŃSKIEJ \\ - UWAGI WSTĘPNE
}

\section{BADANIA JĘZYKOWEGO WYMIARU KOMUNIKACJI Z SACRUM W KRAJACH SŁOWIAŃSKICH}

Język jest narzędziem ekspresji człowieka, jak również narzędziem w kontaktach danych społeczności, poczynając od codziennych do wysublimowanych dyskursów naukowych i dzieł literackich (Markowski i Puzynina 49-50). W jaki sposób język religijny niosący treści pochodzące ze sfery sacrum, może funkcjonować na polu komunikacji świeckiej, narodowej? Jak konstatuje Nina Borisowna Mieczkowskaja, język i religia - это две семиотики, два образа мира, два самых глубоких, несхожих и взаимосвязанных начала в человеческой культуре (Мечковская 36).

Język religijny w krajach byłego ZSRR oraz byłego bloku socjalistycznego do lat 90. zeszłego wieku pozostawał w znacznym zakresie poza zainteresowaniem językoznawców. Badanie procesów, które zachodzą w różnych grupach religijnych, w ciągu ostatnich trzydziestu lat stało się przedmiotem zainteresowania wielu słowiańskich naukowców. W okresie radzieckim społeczność akademicka musiała się godzić z narzuconą przez państwo ideologią i przyjmować jako aksjomaty twierdzenia panującego dyskursu naukowego. Obecnie przedstawiciele kręgów badawczych są stosunkowo nieskrępowani i mogą w sposób niezależny ustalać strategie badawcze, wychodząc od ich celowości naukowej. Należy jednak podkreślić, że analiza języka religijnego jest względnie nowym zagadnieniem w językoznawstwie słowiańskim. Można

Dr MAŁgorZata WideŁ-IgnASZcZAK - adiunkt w Katedrze Translatoryki i Języków Słowiańskich Instytutu Językoznawstwa Katolickiego Uniwersytetu Lubelskiego Jana Pawła II, adres do korespondencji: Katolicki Uniwersytet Lubelski Jana Pawła II; Al. Racławickie 14, 20-950 Lublin; e-mail: mwidel@kul.lublin.pl; ORCID: https://orcid.org/0000-0001-9250-1774. 
wymienić kilka przyczyn takiego stanu rzeczy. Pierwsza - polityczna, dotycząca wszechwładzy ideologii ateistycznej za czasów sowieckich. Druga naukowa, - ponieważ dopiero pod koniec lat 90. zeszłego wieku wektor słowianoznawczych zainteresowań lingwistycznych zwrócił się w stronę problematyki religijnej (Бугаева 6).

Historia i kultura narodu znajdują odzwierciedlenie w języku. Z tego wynika, iż także religia jako forma świadomości społecznej znajduje odzwierciedlenie zarówno w pojedynczych jednostkach języka, jak i uzualnych kliszach językowych. Język religijny to język używany w ramach zachowań religijnych. Według Jerzego Kłoczowskiego to język, którym postuguje się człowiek $w$ sytuacji religijnej (5). Składają się na niego wypowiedzi, w których poszczególne osoby oraz całe społeczności dają wyraz swojej wierze w istnienie rzeczywistości nadprzyrodzonej (Makuchowska 369).

Należy zgodzić się ze stwierdzeniem, że językowy wymiar komunikacji z sacrum zdeterminowany jest światopoglądowo. Nazywany jest on dyskursem religijnym. Maria Wojtak rozpatruje dyskurs jako zbiór wypowiedzi powiązanych z szeroko rozumianym kontekstem, a obszary aktywności komunikacyjnej w ramach dyskursu religijnego wiąże ze sposobem realizowania aktu religijnego, to jest osobliwością tego dyskursu związaną z poszerzeniem przestrzeni dyskursywnej o sferę transcendencji (Wojtak 28-45). Z kolei słowacka badaczka Anna Petrikowa bada prawosławny dyskurs religijny w konfrontacji z dyskursem grecko-katolickim, zwracając uwagę na szczególne formy praktyk duchowych mających na celu zdobycie doświadczenia duchowego, kształtowanie chrześcijańskiego myślenia oraz postrzeganie świata poprzez wybrane kategorie sakralne. W jej rozumieniu dyskurs chrześcijański to forma duchovných praktik zameraných na ziskavanie duchovnej skúsenosti, formovanie krest’anského myslenia, vnímania sveta cez sakrálne kategórie: Boh, Ježiš Kristus, Bohorodička atd' (Petríková 30).

W tej optyce Stanisław Koziara słusznie stwierdza, że u podstaw każdej formy realizacji dyskursy religijnego, jego specyfiki i odmienności na tle innych form językowych tkwi fakt, iż:

w sferze denotacji (odniesienia) dotyka on obszaru transcendencji, rzeczywistości Boga, wszystkiego tego, co wykracza poza obszar bezpośrednich możliwości poznawczych istoty ludzkiej (...). W sferze wyrażenia zaś język religijny pozostaje zawsze językiem ludzkim, ograniczonym zarówno od strony samego systemu gramatycznego reguł jego użycia, jak też możliwości indywidualnych samego użytkownika (69). 


\section{TEOLINGWISTYKA SŁOWIAŃSKA I JEJ KIERUNKI BADAWCZE}

Jak podkreślono powyżej, badania języka religijnego zajmują obecnie ważne miejsce w językoznawstwie słowiańskim, co więcej stanowią odrębny dział badań lingwistycznych zwany teolingwistyką. Jest to nauka z pogranicza lingwistyki i teologii. Zauważyć należy, że chociaż jest to młoda gałąź badań językoznawczych, obejmuje ona już prawie wszystkie nurty badawcze obecne w lingwistyce słowiańskiej (Казаков 27). Refleksja naukowa uczonych skupiona jest między innymi na analizie wpływu języka i religii na świadomość, mentalność człowieka. Idea wyodrębnienia teolingwistyki jako samodzielnej dyscypliny z jasno zarysowanym kręgiem zagadnień, celem oraz zadaniami, obiektem i metodologią badania powstała względnie niedawno. Pierwsze prace naukowe, w których pojawiło się szerokie spektrum problemów związanych $\mathrm{z}$ badaniem języka religijnego $\mathrm{w}$ ramach nowej dyscypliny pojawiły się pod koniec XX wieku.

Walentynyna Postowalowa pisze: $К$ числу дисциплин такого круга относится и формирующаяся в наши дни на стыке теологии (богословия), религиозной антропологии и лингвистики новая синтетическая теолого-лингвистическая дисииплина - «теолингвистика» направленная на изучение взаимосвязи и взаимодействия (интеракции) языка и религии (Постовалова 56). O etymologicznym uzasadnieniu funkcjonowania pojęcia 'teolingwistyka' w językach słowiańskich, jak i zasadności metodologicznej istnienia tej dyscypliny pisze obszernie ukraiński uczony Aleksander Gadomski (Gadomski i Gadomska 7-24, „Теолингвистика: история вопроса” 16-26, „Религиозный язык” 287-292, „Польская теолингвистика” 13-27).

Obecnie badania nad językiem religijnym w nurcie teolingwistycznym rozwijają się w krajach słowiańskich w dwóch głównych kierunkach - są to badania historycznojęzykowe oraz badania współczesnego języka religijnego. Specyfika języka wierzących określana jest cechami szczególnymi religijnej świadomości, co znajduje odzwierciedlenie w językowym obrazie świata tej grupy ludzi i przejawia się w kategoriach mentalnych, w leksyce, w różnym stopniu na poziomie gramatycznym, czy nawet fonetycznym, poziomie etykiety komunikacyjnej, używanych gatunków mowy / tekstu i in. Jednym z perspektywicznych kierunków synchronicznej teolingwistyki jest teolingwistyka porównawcza, celem której jest badanie sfery religijnej w różnych językach (Кончаревич 14-22). Refleksją lingwistyczną objęte są w niej wszystkie poziomy systemu języka, jednak najbardziej relewantnymi okazują się poziomy leksyki i frazeologii. 
Należy konstatować, że przy opisie języka konfesyjnego realizowane jest wieloaspektowe, interdyscyplinarne podejście, gdyż przedmiot badania wyróżnia się wysokim stopniem skomplikowania i wieloma planami badawczymi. Takie podejście zakłada zintegrowane przedstawienie analizowanego materiału i przywoływanie informacji z różnych dziedzin nauki, takich jak teologia, religioznawstwo, historia kościoła, kulturologia, psychologia, kognitywistyka, socjolingwistyka.

Dla dalszych ustaleń perspektyw badawczych współczesnego języka religijnego punktem odniesienia są obszary, potwierdzone bogatą literaturą przedmiotu - są to między innymi następujące zagadnienia: teologia, filozofia religii, filozofia języka, semantyka językoznawcza, stylistyka funkcjonalna (analiza języka i stylu religijnego traktowanego jako odmiana funkcjonalna języka ogólnego), teoria gatunków mowy (w tym nurcie sytuują się prace, które rozpatrują różnorodność genologiczną języka religijnego oraz te, które badają sytuacje komunikacyjne w sferze sacrum), teoria dyskursu, językowy obraz świata, a także socjolingwistyka, etnolingwistyka i lingwokulturologia.

W niniejszym artykule pragnę skupić uwagę na socjolingwistycznych uwarunkowaniach funkcjonowania słownictwa religijnego, wychodząc z założenia, za Ireną Bajerową, że język religijny to odmiana języka ogólnego, będąca środkiem komunikacji w życiu religijnym. Główne funkcje tego języka to: „1. kontaktowanie się człowieka ze światem nadprzyrodzonym; 2 . opis ludzkiej wizji tego świata; 3. sformułowanie odnośnego zespołu wartości i nakazów etycznych” („Szanse języka religijnego” 102). Badaczka konstatuje: „Język, współtworząc życie religijne, ulega potrzebom tej sfery kultury i potrzeby te odpowiednio go modelują. Tak utworzyć się może specjalna odmiana funkcyjna, wyraziście (dzięki odpowiednim cechom językowym) skorelowana z tymi sytuacjami komunikacyjnymi" (Wptyw życia religijnego 10).

W najbardziej obszernej pracy poświęconej cechom szczególnym języka wyznawców prawosławia z uwzględnieniem mentalnych różnic między wierzącymi i niewierzącymi Irina Bugajewa podkreśla, iż badania historyczne języka rosyjskiego świadczą o wpływie chrześcijaństwa na mentalność narodu, co niezwykle wyraziście znalazło potwierdzenie w leksyce i frazeologii (Бугаева 45). Badania dotyczące języka religijnego zdeterminowane są koniecznością uwzględnienia wpływu chrześcijaństwa na mentalność poszczególnych narodowości, gdyż można mówić o dominacji chrześcijańskiej mentalności poszczególnych narodów słowiańskich - zarówno Slavia Latina, jak i Slavia Orthodoxa. W niektórych regionach, na przykład we wschodniej 
Słowacji, to właśnie koegzystowanie różnych konfesji chrześcijańskich wpływa na rozwój sytuacji społeczno-kulturowej oraz współczesny słowacki język religijny (Petríková 8). Uwzględnienie zatem tego kryterium jest relewantną perspektywą, z której można analizować współczesny język religijny we wszystkich krajach słowiańskich. Osoby wyznające tę sama religię w danym państwie stanowią bowiem jedną wspólnotę językową, połączone są one wspólnymi korzeniami historyczno-kulturowymi i religijnymi, ich komunikacja językowa realizowana jest za pomocą wspólnego subkodu językowego.

\section{JĘZYK RELIGIJNY \\ JAKO OBIEKT BADAŃ SOCJOLINGWISTYCZNYCH}

Obiektem badań socjolingwistycznych w rozpatrywanym przez nas nurcie jest język religijny jako szczególne werbalne odzwierciedlenie religijnej świadomości językowej. Podczas opisywania granic obiektu badań w wypadku analizy grup religijnych rozróżnienie może być przeprowadzone za pomocą pojęcia tożsamości religijnej. Charakter i sposoby konstruowania tożsamości mogą wskazywać bądź na rozmytość, bądź na integralność grupy. Pod pojęciem tożsamości religijnej rozumiem formę grupowej świadomości, powstałej w procesie przypisywania sobie i innym określonych cech, której charakter nie jest określany wyłącznie poprzez rzeczowe oznaki kulturowe, ale w której wyobrażenia o społecznościach sprzyjają formowaniu pewnych ram dla postępowania zbiorowego - np. w ramach kultu (Воронков і Освальд 18).

Przedmiotem badania są zjawiska językowe na różnych poziomach języka oraz w tekstach różnych typów i gatunków w danym środowisku konfesyjnym (tworzącym środowisko komunikacyjne (Петрикова 2010), według innej terminologii - strefę socjolingwistyczną) niezależnie od wieku, płci, poziomu wykształcenia ogólnego i teologicznego, sytuacji materialnej i społecznej (Бондалетов 85-86). Badacze zgodnie podkreślają „wymiar wspólnotowy" języka religijnego, dzięki któremu pełni on funkcję zespalania społeczności (Bajerowa i Puzynina 19). Celem tak wieloaspektowych badań lingwistycznych jest opis cech wyróżniających język wyznawców danej religii oraz relacji języka religijnego i języka ogólnonarodowego. Specyfikę języka konfesyjnego należy upatrywać w cechach szczególnych świadomości (tożsamości) człowieka religijnego, co znajduje odzwierciedlenie w językowym obrazie świata tej grupy ludzi i przejawia się w kategoriach 
mentalnych, w leksyce, a nawet na poziomie etykiety komunikacyjnej czy gatunków mowy.

Rozpatrując perspektywy badań socjolingwistycznych w nurcie teolingwistyki słowiańskiej należy podkreślić, że z uwagi na to, iż cel, jakim jest socjolingwistyczny opis języka religijnego, jest niezwykle szeroko zakrojony, niezbędna jest ekscerpcja różnorodnych aktualizacji wypowiedzi religijnych obecnych w poszczególnych językach słowiańskich - takich jak: literatura religijna, prasa, słowniki i encyklopedie, a także język mówiony. W centrum badania znajdą się obserwacje z zakresu języka obecnego w danej wspólnocie konfesyjnej w ramach kultu, na peryferiach zaś obecność komponentów sfery religijnej w sferze profanum. Wynika $\mathrm{z}$ tego, że analizie podlega nie tylko język liturgiczny, język duchownych, autorów publikacji teologicznych, studentów szkół teologicznych, ale także wiernych w parafiach, uczestników pielgrzymek itp. Język mówiony powinien być przedstawiony tak jak pisemny, uwzględniając zróżnicowanie gatunkowe - dialogi, monologi, polilogi, wywiady, sytuacje komunikacyjne zaś powinny nosić oficjalny i nieoficjalny charakter.

Zasadnicze zadania socjolingwistycznej analizy języka konfesyjnego można określić w następujący sposób:

1. Opis funkcji komunikacyjnych i pragmatycznych w ramach danego religiolektu na tle języka ogólnonarodowego.

2. Pokazanie zmian $w$ języku ogólnym $w$ rezultacie aktywizacji komponentu religijnego i szeroko pojętego wpływu języka religijnego na język świecki, jak i w odwrotnym kierunku. Opis jednostek języka religijnego występujących/niewystępujących w swobodnej dystrybucji z ich uzualnymi odpowiednikami.

3. Analiza wyekscerpowanego materiału źródłowego z punktu widzenia związku z normami współczesnego języka narodowego oraz udziału w mowie wierzących (niekoniecznie na religijne tematy) jednostek językowych konfesyjnej proweniencji.

4. Opis typowych cech subkodu wierzących - na poziomie fonetyki, grafiki, ortografii, morfologii, słowotwórstwa i leksyki (Карасик 21).

5. Zbadanie stopnia konstytuowania szczególnego systemu stylistycznego i genologicznego poszczególnych gatunków religiolektu, który potwierdza zasadność jego wydzielenia.

Tak zarysowany cel pozwoli, jak się wydaje, przedstawić status języka religijnego jako religiolektu, będącego częścią składową poszczególnych współczesnych języków słowiańskich. 
Drugim, równie ważnym celem badań socjolingwistycznych, jest doprecyzowanie socjalnego zróżnicowania współczesnych języków narodowych poprzez przebadanie języka określonej grupy użytkowników tego języka, połączonych przynależnością konfesyjną, stanowiących swojego rodzaju wspólnotę językową. Mowa jest zatem o określeniu stopnia i charakteru wpływów na religiolekt procesów społecznych i ideologicznych. W tym celu niezbędny jest opis warunków funkcjonowania poszczególnych konfesji w krajach słowiańskich. Nie bez znaczenia będzie fakt, czy wyznanie jest dominujące w danym kraju, czy też jego wyznawcy tworzą mniejszość religijną. Na funkcjonowanie mniejszości religijnej w swoim kraju bowiem wpływ miały i mają procesy polityczne, kulturowe i historyczne, co pociąga za sobą powstanie nowego podsystemu w ramach języka ogólnonarodowego. Sytuację taką obserwujemy na przykładzie funkcjonowania języka rosyjskiego proweniencji rzymskokatolickiej.

Język religijny jest zatem samodzielnym mikrosystemem, który charakteryzuje się szczególnymi parametrami i realizuje wieloaspektowe możliwości funkcjonowania. Jak konstatuje Ewa Golachowska, o specyfice tego języka nie świadczy odpowiedni zasób słów, a jedynie przynależność do sfery sacrum. Taki sposób myślenia bliski jest socjolingwistyce, która tradycyjnie wyróżnia sferę religijna wśród innych sfer użycia języków (Golachowska 53).

Przy socjolingwistycznym badaniu i opisie języka wierzących należy realizować wieloaspektowe i interdyscyplinarne podejście. Jest ono zdeterminowane tym, iż przedmiot badania charakteryzuje się dużym stopniem złożoności - zarówno pod względem niejednorodności podejść do samego języka religijnego we współczesnym językoznawstwie, jak i różnego statusu społecznego użytkowników języka (Golachowska 19-33). Dla najbardziej pełnej i wszechstronnej analizy języka religijnego konieczne jest interdyscyplinarne podejście także dlatego, iż wymaga zintegrowanego przedstawienia analizowanego materiału z różnych dziedzin nauki, takich jak: teologia, filozofia, kulturologia, psychologia, socjolingwistyka. W tym celu zasadnym jest zastosowanie metody porównania interdyscyplinarnego oraz metod stricte socjolingwistycznych takich jak: zbiór informacji, obserwacja, ankietowanie, analiza ustnych i pisemnych tekstów i in. (por. Lubaś 31-49, Shumarova 6469, Байбер 257-291).

$\mathrm{Z}$ punktu widzenia socjologicznego rozwarstwienia języka religijnego należy także rozpatrywać sam akt mowy języka religijnego. Irena Bajerowa precyzuje cechy składników, które tworzą jego charakterystyczny uzus, a mianowicie: 
1. nadawcy i odbiorcy (sacrum, wspólnota, indywiduum),

2. rzeczywistości (sacrum, kontakt z sacrum, wartości i nakazy, życie wspólnoty),

3. kodu (specjalne słownictwo, częsta dwupoziomowość wypowiedzi),

4. sytuacji (rytuał, nauczanie i informowanie, modlitwa indywidualna)

5. komunikatu (opis sacrum, modlitwa, akty sprawcze, reguły postępowania, opis wspólnoty) („Swoistość języka” 217-240).

Dla tak zarysowanego aktu mowy języka religijnego wyróżnia podstawowe cechy językowe takie jak: ekspresja, prostota, formułowość, dialogowość, perswazyjność i tradycyjność - uwzględnienie udziału, których jest niezbędne, w mojej ocenie, do ustalenia także socjolingwistycznego statusu języka. Autorka podkreśla istnienie „osobliwego kodu semantycznego”. Trudno nie zgodzić się z twierdzeniem I. Bajerowej, że język religijny nie powinien być ograniczony treściowo oraz pod względem zasięgu społecznego i uznany tylko za odmianę środowiskową, bo religia przecież za taką nie może być uważana („Swoistość języka” 217-240).

Podejmując zagadnienia analizy języka religijnego w danym państwie należy spojrzeć na nie także przez pryzmat struktury konfesyjnej. Naturalnym jest, że badacze podejmując zagadnienia polskiego języka religijnego w swoich doświadczeniach bazują głównie i w największym stopniu na tym, który używany jest w Kościele rzymskokatolickim, zaś rosyjscy językoznawcy skupiają refleksję badawczą na przeważającym w Rosji wyznaniu, tj. prawosławiu. Taka postawa jest zrozumiała i uzasadniona dominacją określonych kultur religijnych w danych państwach. Nie wpływa to na cechy stanowiące differentiae specyficae języka religijnego, jednakże niemożliwy jest właściwy i całościowy opis języka religijnego ograniczony do badań czysto językoznawczych, dla pełnego obrazy powinny im w miarę możliwości towarzyszyć rzetelne analizy lingwokulturowe i socjolingwistyczne.

Język religijny jest niezaprzeczalnie jednym z rodzajów kodu występującym w szeroko rozumianej komunikacji społecznej, a głównym jego celem jest eksplikacja stosunku członków danej wspólnoty konfesyjnej do sfery transcendentnej. W Rosji, szerzej w krajach byłego ZSRR - językiem sakralnym w środowisku katolickim był długie lata uznawany język polski. Stąd liczne zapożyczenia z języka polskiegoб nр.: костел, облатка, ксендз. Ро latach 90., kiedy liczba wiernych narodowości polskiej drastycznie się zmniejszała stwierdzono, że dla realizacji uniwersalnej misji Kościoła występuje wyraźna potrzeba tłumaczenia tekstów na języki narodowe - rosyjski, białoruski, ukraiński. Spotkało się to z ze zdecydowana krytyką środowisk polskich, ale 
zamysł ten został zrealizowany, a zapożyczenia z języka polskiego są wypierane i zastępowane. Odmienną sytuację socjolingwistyczną można zaobserwować obecnie w Serbii - z uwagi na to, że dominującym wyznaniem w Serbii jest prawosławie, a katolicy stanowią mniejszość religijną, teksty katolickie nie są thumaczone na język serbski - literatura religijna jest obecna tylko po chorwacku. Nie ma potrzeby wykonywania tłumaczeń na język serbski, z uwagi na bliskie pokrewieństwo obu języków nie występuje pragmatyczne uzasadnienie, gdyż język jest w pełni zrozumiały dla wiernych. Bariery nie stanowi także alfabet łaciński języka chorwackiego, ponieważ Serbowie używają dwóch alfabetów cyrylickiego i łacińskiego. Liturgia jest sprawowana po chorwacku - niemożliwy jest zatem opis lingwistyczny współczesnego katolickiego języka serbskiego w jego wariancie pisemnym, jednakże komunikacja między wiernymi (np. w ramach wspólnot religijnych) odbywa się w języku serbskim.

Reasumując, mówiąc o postulatach badań socjolingwistycznych w nurcie teolingwistyki słowiańskiej, można wyodrębnić cztery obszary badań:

1. pierwszy to badanie kontaktów językowych, zwłaszcza kodów wchodzących w skład kontinuum języka wyznawców danej konfesji;

2. drugi to obserwacja życia wyrazów i zmian historyczno-społecznych w obrębie leksyki religijnej;

3. trzeci, z kolei, to opis wariantów językowych (zwłaszcza leksykalnych);

4. czwarty - rekonstrukcja obecnych wśród użytkowników języków słowiańskich postaw wobec języka religijnego, tożsamości religijnej.

Biorąc pod uwagę płaszczyznę socjolingwistyczną w ujęciu teolingwistycznym, należy konstatować, że język badany z tej perspektywy utożsamiany jest z systemem, składającym się ze słownika i zbioru reguł (składniowych, semantycznych i ewentualnie pragmatycznych), a zadaniem socjolingwisty jest odtworzenie tych reguł, które stoją u podstaw zachowań użytkowników języka. Druga perspektywa, z której prowadzone są badania nad językiem, polega na ujmowaniu języka jako zespołu działań. „Język badany $z$ tej perspektywy nie jest tożsamy z wiedzą poszczególnego człowieka, lecz 'dzieje się’ pomiędzy ludźmi, jest kompleksem zachowań społecznych" (Gizbert-Studnicki 14). Język funkcjonuje w społeczeństwie, przejawia się w postaci zespołu interakcji społecznych. Celem badań lingwistycznych jest odkrycie prawidłowości, wedle których interakcje te następują.

Na podstawie analizy dyskursów religijnych w krajach słowiańskich można postawić hipotezę, że osoby wyznające tę samą wiarę tworzą jedną wspólnotę językową połączoną wspólnymi kontaktami historyczno-kulturo- 
wymi i religijnymi, a realizując komunikację w sferze zarówno sacrum, jak i profanum wykorzystują wspólny subkod językowy.

\section{BIBLIOGRAFIA}

Bajerowa, Irena, i Jadwiga Puzynina. „Język religijny. Aspekt filologiczny”. Encyklopedia katolicka, t. 8, red. Antoni Bednarek i in., Towarzystwo Naukowe Katolickiego Uniwersytetu Lubelskiego, 2000, ss. 19-20.

Bajerowa, Irena. „Swoistość języka religijnego i niektóre problemy jego skuteczności”. Łódzkie Studia Teologiczne, nr 3, 1994, ss. 11-17.

Bajerowa, Irena. „Szanse języka religijnego w świecie kultury masowej”, Teologia - kultura wspótczesność. Materiały z sympozjum w Instytucie Teologicznym w Tarnowie 9 IV 1994, red. Zdzisław Adamek, Wydawnictwo „Biblos”, 1995, ss. 99-113.

Bajerowa, Irena. „Wpływ życia religijnego na język ogólnopolski (próba systematyzacji opisu historycznego". O języku religijnym. Zagadnienia wybrane, red. Irena Bajerowa, Maria Karpluk, Zenon Leszczyński, Towarzystwo Naukowe KUL, 1993, ss. 7-18.

Bayber, Duglas, „Analiticheskayaramka dlya izucheniya yazykovykh registrov”, red. i per. Nikolay Borisovich Vakhtin, Sotsiolingvistikai sotsiologiya yazyka. Khrestomatiya, Izdatel'stvo Yevropeyskogo universiteta v Sankt-Peterburge, 2012, ss. 257-291 [Байбер, Дуглас, Аналитическая рамка для изучения языковых регистров, ред. и пер. Николай Борисович Вахтин, Социолингвистика и сочиология языка. Хрестоматия, Издательство Европейского университета в Санкт-Петербурге, 2012, ss. 257-291].

Bondaletov, Vasiliydanilovich. Sotsial'naya lingvistika. Izdatel'stvo Lenand, 2015 [Бондалетов, Василий Данилович. Соџиальная лингвистика. Издательство Ленанд, 2015].

Bugayeva, Irina Vladimirovna. Yazyk pravoslavnoy sfery: sovremennoye sostoyaniye, tendentsii razvitiya. Dissertatsiya na soiskaniye uchenoy stepeni doktora filologicheskikh nauk (na pravakh rukopisi). 2010 [Бугаева, Ирина Владимировна. Язык православной сферы: современное состояние, тенденции развития. Диссертация на соискание ученой степени доктора филологических наук (на правах рукописи). 2010].

Gadomski, Aleksander, i Halina Gadomska. „Teolingwistyka polska w kontekście teolingwistyki słowiańskiej”, Prace naukowe Akademii im. Jana Dlugosza w Częstochowie. Językoznawstwo", nr 10, 2014, ss. 7-24.

Gadomskiy, Aleksandr Kazimirovich i Galina Petrovna Gadomskaya. „Izucheniye religioznoy leksiki v ukrainskoy teolingvistike XX-XXI st.”. Teolingvistička proučavanja slovenskih jezika, red. Jasmina Grković-Mejdžor, Kseniya Koncharević. Srpska akademija nauka i umetnostib 2013, ss. 45-70 [Гадомский, Александр Казимирович, и Галина Петровна Гадомская. „Изучение религиозной лексики в украинской теолингвистике XX-XXI ст.”. Теолингвистичка проучавања словенских језика, ред. Јасмина Грковић-Мејџор, Ксения Кончаревић. Српска академија наука и уметностиб 2013, ss. 45-70].

Gadomskiy, Aleksandr Kazimirovich. „Pol'skaya teolingvistika narubezhe XX-XXI stoletiy”. Teolingvistika, red. Aleksandr Kazimirovich Gadomskiy, Kseniya Koncharević. Pravoslavni bogoslovski fakultet - Institut za teološka istraživanja, 2012, ss. 13-27 [Гадомский, Александр Казимирович. „Польская теолингвистика на рубеже XX-XXI столетий”. Теолин- 
гвистика, ред. Александр Казимирович Гадомский, Ксения Кончаревич. Православни богословски факултет - Институт за теолошка истраживања, 2012, ss. 13-27].

Gadomskiy, Aleksandr Kazimirovich. „Religioznyy yazyk - teolingvistika- yazykoznaniye”. Uchenyye zapiski Tavricheskogo natsional'nogo universiteta - Filologiya, 20 (59), 1, 2007, ss. 287-292 [Гадомский, Александр Казимирович. „Религиозный язык - теолингвистика - языкознание”. Ученые записки Таврического начионального университета - Филология, 20 (59), 1, 2007, ss. 287 -292].

Gadomskiy, Aleksandr Kazimirovich. „Teolingvistika: istoriya voprosa”. Uchenyye zapiski Tavricheskogo natsional'nogo universiteta - Filologiya, 18 (57), 1, 2005, ss. 16-26 [Гадомский, Александр Казимирович. „Теолингвистика: история вопроса”. Ученые записки Таврического национального университета - Филология, 18 (57), 1, 2005, ss. 16-26].

Gizbert-Studnicki, Tomasz. Język prawny z perspektywy socjolingwistycznej. Państwowe Wydawnictwo Naukowe, 1986.

Golachowska, Ewa. Jak mówić do Pana Boga? Wielojęzyczność katolików na Białorusi na przetomie XX i XXI wieku. Instytut Slawistyki PAN. Wydawnictwo Agade, 2012.

Grabias, Stanisław. Język $w$ zachowaniach społecznych. Podstawy socjolingwistyki i logopedii. Wydawnictwo Uniwersytetu Marii Curie-Skłodowskiej, 2019.

Karasik, Vladimir Il'ich. Yazyk sotsial'nogo statusa. Izdatel'stvo Gnozis, 2002 [Карасик, Владимир Ильич. Язык сочиального статуса. Издательство Гнозис, 2002].

Kazakov, Grigoriy. Sakral'naya leksika v sisteme yazyka. Izdatel'stvo KDU, 2016 [Казаков, Григорий. Сакральная лексика в системе языка. Издательство КДУ, 2016].

Kłoczowski, Jerzy. „Język, którym mówi człowiek religijny”. Znak, nr 12 (487), 1995, ss. 5-17.

Koncharevich, Kseniya. „K teoretiko-metodologicheskomu obosnovaniyu sopostavitel'noy teolingvistiki (na materiale russkogo i serbskogo yazykov)". Dostizheniya i perspektivy sopostavitel'nogo izucheniya russkogo $i$ drugikh yazykov, red. Vera Belokapich-Shkuntsa. Slavistichko drushtvo Srbije, 2012, ss. 14-22 [Кончаревич, Ксения. „К теоретико-методологическому обоснованию сопоставительной теолингвистики (на материале русского и сербского языков)". Достижения и перспективы сопоставительного изучения русского и других языков, ред. Вера Белокапич-Шкунца. Славистичко друштво Србије, 2012, ss. 14-22].

Koziara, Stanisław. „Wokół współczesnych problemów komunikacji międzyludzkiej i języka religijnego". Teologia - kultura - współczesność. Materiały z sympozjum w Instytucie Teologicznym w Tarnowie 9 IV 1994, red. Zdzisław Adamek. Biblos, 1995, ss. 63-75.

Lubaś, Władysław. Studia socjolingwistyczne. Wydawnictwo Uniwersytetu Opolskiego, 2013.

Makuchowska, Marzena. „Język religijny”. Język polski. Najnowsze dzieje języków słowiańskich, red. Stanisław Gajda. Wydawnictwo Uniwersytetu Opolskiego, 2001, ss. 369-402.

Markowski, Andrzej, Puzynina, Jadwiga. „Kultura języka”. Współczesny język polski, red. Jerzy Bartmiński. Wydawnictwo Uniwersytetu Marii Curie-Skłodowskiej, 2001, ss. 49-71.

Mechkovskaya, Nina Borisovna. Yazyk i religiya: Posobiye dlya studentov gumanitarnykh vuzov. Agentstvo „FAIR”, 1998 [Мечковская, Нина Борисовна. Язык и религия: Пособие для студентов гуманитарных вузов. Агентство „ФАИР”, 1998].

Petríková, Anna. Náboženský diskurz. Rečové stratégie a taktiky v homiliách. Filozofická fakulta Prešovskej univerzity v Prešove, 2019. 
Petrikova, Anna. Propoved' kak kommunikativno-kul'trunyy fenomen. Filozofická fakulta Prešovskej univerzity v Prešove, 2010 [Петрикова, Анна. Проповедь как коммуникативнокультруный феномен. Filozofická fakulta Prešovskej univerzity v Prešove, 2010].

Postovalova, Valentina Il'inichna. „Teolingvistika v sovremennom gumanitarnom poznanii: istoki, osnovnyye idei i napravleniya”. Nauchno-pedagogicheskiy zhurnal Vostochnoy Sibiri Magister Dixit, nr 4, 2012, ss. 56-103 [Постовалова, Валентина Ильинична. „Теолингвистика в современном гуманитарном познании: истоки, основные идеи и направления”. Научнопедагогический журнал Восточной Сибири Magister Dixit, nr 4, 2012, ss. 56-103, 10 сентября 2018, cyberleninka.ru/article/n/teolingvistika-v-sovremennom-gumanitarnom-poznaniiistoki-osnovnye-idei-i-napravleniya]. Dostęp 10.09.2018.

Shumarova, Nataliya. Podstawy socjolingwistyki. Wyższa Szkoła Społeczno-Gospodarcza, 2004.

Voronkov, Viktor, i Ingrid Osval'd. „Vvedeniye. Postsovetskiye etnichnosti”, Konstruirovaniye etnichnosti. Etnicheskiye obshchiny Sankt-Peterburga, red. Viktor Voronkov, Ingrid Osval'd. Izdatel'stvodmitriy Bulanin, 1998, ss. 6-36 [Воронков, Виктор, н Ингрид Освальд. „Введение. Постсоветские этничности”, Конструирование этничности. Этнические общины СанктПетербурга, ред. Виктор Воронков, Ингрид Освальд. Издательство Дмитрий Буланин, 1998, ss. 6-36].

Wojtak, Maria. Współczesne modlitewniki w oczach językoznawcy. Studium genologiczne. „Teolingwistyka” 9. Biblos, 2011.

\section{PERSPEKTYWY BADAŃ SOCJOLINGWISTYCZNYCH W NURCIE TEOLINGWISTYKI SŁOWIAŃSKIEJ - UWAGI WSTĘPNE}

\section{Streszczenie}

Artykuł poświęcony jest opisowi perspektyw socjolingwistycznego badania języka religijnego funkcjonującego $\mathrm{w}$ sferze słowiańskiej z uwzględnieniem mentalności poszczególnych narodów oraz zróżnicowania religiolektu wierzących i niewierzących. Stwierdzono, iż badania teolingwistyczne podkreślają wpływ chrześcijaństwa na mentalność poszczególnych narodowości, stąd można mówić o dominacji chrześcijańskiej mentalności poszczególnych narodów słowiańskich, co znalazło odzwierciedlenie przede wszystkim w leksyce i frazeologii. Postawiono hipotezę, że osoby wyznające tę samą wiarę tworzą jedną wspólnotę językową, połączoną wspólnymi kontaktami historyczno-kulturowymi i religijnymi, realizują komunikację wykorzystując wspólny subkod językowy.

Slowa kluczowe: socjolingwistyka; teolingwistyka; religiolekt. 


\section{THE PERSPECTIVES OF SOCIOLINGUISTIC RESEARCH WITHIN THE REALM OF SLAVIC THEOLINGUISTICS - INTRODUCTORY REMARKS}

\section{Summary}

The paper provides a description of the prospects of sociolinguistic studies of the religious language functioning in the Slavonic sphere, taking into account the mentalities of individual nations and the diversity of the religiolect of believers and unbelievers. It was found that theolinguistic studies emphasise the influence of Christianity on the mentalities of individual nationalities; thus, one can say about the domination of Christian mentality of different Slavonic nations, which is reflected mainly in lexis and phraseology. A hypothesis was formulated that people of the same faith form one linguistic community, linked by common historical-cultural and religious contacts, and communicate with the use of a common linguistic subcode.

Key words: sociolinguistics; theolinguistics; religiolect. 